\title{
Strategy for the Implementation of the Village Financial System Application Effectively and Efficiently
}

\author{
Hesti Irnanta, Nur Latifa Isnaini Putri \\ Department of Management, STIE Widya Gama Lumajang \\ Email: irnantahesti25@gmail.com
}

\section{A R T I C LE IN F O}

Received:

13 January 2021

Revised:

6 March 2021

Accepted:

13 March 2021

\begin{abstract}
A B S T R A C T
This study aims to assess the performance of the village government from the use of the SISKEUDES (Village Financial System) application in improving the quality of financial accountability in the village of Tanjungsari, Umbulsari District, Jember Regency. This research uses qualitative methods using a descriptive approach. Data obtained from observations and interviews with informants, in this case the village government, from the village head, village secretary, finance officer, financial staff, and planning staff, directly from the results of the interview data reduction, data presentation and withdrawal were carried out. Conclusion.
\end{abstract}

Keywords: Budget, Village Financial System, Accountability

Cite this as: Irnanta, H., Putri, N. L. I. (2021). Strategy for the Implementation of the Village Financial System Application Effectively and Efficiently. Wiga : Jurnal Penelitian Ilmu Ekonomi, 11(1), 50-56. https://doi.org/10.30741/wiga.v11i1.653

\section{INTRODUCTION}

At present, regional autonomy does not only reach the regional government level but has expanded to a lower level government, namely the village government. This is of course very good and we need to welcome it well too. However, considering the mechanism or governance of the village government in various aspects which of course requires expertise or competence, the village government needs good and adequate resource capacity (Rohman, et al, 2018: 4).

Law number 6 of 2014 states that a village is a legal community unit that has territorial boundaries that are authorized to regulate and administer government affairs, the interests of the local community based on community initiative, rights of origin, and traditional rights that are recognized and respected in the government system of the Unitary State of the Republic. Indonesia. Village institutions are institutions that support the implementation of village government, implementation of village development, guidance and empowerment of village communities. Therefore, village institutions must work together and be integrated to achieve the goals of a prosperous village. Village community institutions function as a forum for village community participation in development, governance, society. 
Village government is the administration of government affairs of the Unitary State of the Republic of Indonesia. The village is domiciled in the regency / city area (BPKP, 2015). Whereas the definition of village government according to law number 6 of 2014 concerning villages and Government Regulation number 43 of 2014 concerning villages, what is meant by village government is the implementation of government affairs and the interests of the local community in the government system of the Unitary State of the Republic of Indonesia and the village government is the Village Head or those who are referred to by other names are assisted by village officials as elements of village government administration.

The village government, in this case the village leader or head, has the duties and authorities that must be carried out, namely the structured and good administrative tasks of the village government. Village administration is the whole process in the form of recording data and information about the implementation of village governance in various village administration books. The village administration process must be carried out with a simple and easy process, but still prioritizing the principle of accountability (Rohman, et al, 2018: 53).

The administrative process has the intent and purpose for the smooth running of the service processes that exist in the village government itself. The purpose of holding village administration is to organize the implementation of village administration so that it can work better in carrying out village administration that is increasingly broad and effective in line with the dynamics developing in the community. With the existence of village administration, the process of implementing village government can be carried out in an orderly, systematic and structured manner.

Financial administration, recording data and information activities regarding village financial management in the financial administration book. In this case, what is meant by village finance is APBDesa, which has an important role in operating all village development activities. The APBDesa is a reflection of the performance and capacity of the village government in financing development for the welfare of the village community. However, seeing the reality that there are still many complaints from the community regarding misappropriation of funds or mismatching of APBDesa fund allocations by the village government.

One of the commitments from the government in supporting the supervision of village fund management is stated in the Circular of the Director General of Village Government Development of the Ministry of Home Affairs number 135/8350 / BPD dated 27 November 2015 concerning the Village Financial Management Application which states that the Finance and Development Audit Agency (BPKP) has collaborated with the Ministry Disadvantaged Regions and Transmigration (PDTT) villages develop a village fund management system based on an accounting information system, namely the Village Financial System (Siskeudes) application.

The Siskeudes application is an application developed by the BPKP in order to improve the quality and management of village finances in order to estimate supervision, especially in the allocation of village funds. This Siskeudes application was developed to make financial reporting more transparent and accountable in accordance with accounting financial reporting requirements.

The Siskeudes application is still full of problems that occur in its application in the village, one of the problems is the lack of human resources and constraints in data input. There are advantages to the Siskeudes application but there are also disadvantages to the Siskeudes application. Ease of village financial management, ease of use of application features that are equipped with an internal control system, are the advantages of this application. But on the other hand, there are still deficiencies in this application, namely the difficulty in understanding the use of applications that are said to be relatively new among the village government, so there is still a need to improve the quality of the human resource aspect. 


\section{METHOD}

This study used qualitative research methods. The primary data used was in the form of direct interviews with the officials of the Tanjungsari Village, Jember. Secondary data sources come from reports and documents that are closely related to the object being discussed.The steps that can be taken in a qualitative descriptive analysis, namely (Sugiono, 2010): 1. The researcher begins to organize all the data that has been collected 2. Reads the data as a whole and makes marginal notes about the data that is considered important then encodes the data 3 . Finds and classifies the statements felt by respondents by doing horizonaliting, namely any statements that are not relevant to topics and questions or statements that are repetitive or overlapping are eliminated. Reducing data, sorting, centralizing, and simplifying new data obtained from raw research that appears from written notes in the field 5. Presentation of data, namely by arranging and compiling information in a single, selective and understandable form 6. Formulation in conclusion, namely by conducting a review in the field to test the truth and validity of the meaning that appears there. The results obtained are interpreted, then presented in a narrative form.

\section{RESULTS AND DISCUSSION}

Umbulsari District is a sub-district located in Jember Regency in East Java Province. Umbulsari District has an area of about $70.50 \mathrm{Km} 2$. Umbulsari sub-district has 10 villages, one of which is Tanjungsari village which has the ability to allocate village funds using the village financial system (SISKEUDES).

The data were collected from the results of interviews with several informants, in this case the Tanjungsari village government, along with informant data:

Table 1.1 Research Informant Data

\begin{tabular}{|c|c|c|}
\hline No. & Name & Position \\
\hline 1 & Sabuktiyono & Village head \\
\hline 2 & Susiana & village secretary \\
\hline 3 & Angga Oktavian S., SE. & Planning Staff \\
\hline 4 & Sutiami & Head of Finance \\
\hline 5 & Anita Oktaviani, SE. & Financial staff \\
\hline
\end{tabular}

Source: Tanjungsari Village Government

Financial planning in Tanjungsari village is in accordance with the flow where the village government prepares the Village RPJM which is then compiled into a periodic Village RKP and is also in accordance with village regulations. In the preparation of the Tanjungsari Village RPJM and the Village RKP the timeframe is determined in accordance with the perdes, namely the one year Village RKP and the Village RPJM according to the term of office of the village head, which is 6 years.

Budgeting in the village of Tanjungsari, both transactions in the form of revenue and expenditure, has been well implemented by the village treasurer, especially since the use of the Siskeudes application because all activities are recorded in more detail and in accordance with reality because everything is collected in one door.

The Village Financial System application is a form of innovative village financial reporting system that prioritizes accessibility, as well as being effective and time efficient. This application was developed by BPKP so that villages throughout Indonesia are able to create accountable financial 
reports and reduce the occurrence of fraud that is often done by the village government due to a lack of control from the center. The existence of a village financial implementation system certainly provides both advantages and disadvantages for its users. Advantages

Siskeudes makes it easy for the village government to manage village finances, for now the application can still be used offline which is equipped with implementation instructions and application manuals so as to create more accurate financial reports. The weakness of this application is that it often experiences errors during the input process and sometimes the data is not properly inputted or the entry page does not appear.

The accountability related to the program of the village head that is implemented must be able to show if the program to be built can run well and what efforts can be made so that the planned program can run optimally.

Human resources, in this case the village government managing the village financial system of Tanjungsari, always try to upgrade themselves so that it is in line with application updates that are always carried out every year, so that the village government is able to handle problems or obstacles when tasked with operating the village financial system application (Siskeudes). Seeing from the theory which says that an accountable government is a government with a concept relating to external standards that determine the correctness of a good bureaucratic action.

In carrying out accountability or bookkeeping, it is hoped that the Tanjungsari village government will be able to produce accounting reports on the realization of the APBDesa, reports per activity, reports on monthly, quarterly budget realization, and reports on village assets. In accordance with the results of interviews conducted by village government researchers, Tanjungsari said that they had been able to make and compile all requested reports according to the sub-menus or items of the Siskeudes application which were structured and complete as a whole. Evaluation of village finances has been carried out from the start of the village budget down to the village government, apart from internal village parties there are other parties who must know how village funding works, and also oversee the process of using funds from the government in the village.

The process of monitoring and evaluation is carried out in stages in an ongoing period in order to minimize errors in the use of village funds and also direct the village government if they still do not understand the use of the Sikeudes application that is run from the planning stage to the final stage, namely reporting.

After all processes have been carried out in stages and have been checked, what will be done is the input process into the siskeudes application. Reports that will be inputted into the previous system will be made by village officials in charge, such as administration reports will be made by the village treasurer. After the reports are completed, they will be given to the village head to be checked and get approval to be input into the system. The village treasurer and special operator of Siskeudes in Tanjungsari village can only enter reports into the system. All data inputted will be adjusted to the system, the input process must be carried out properly because if there is wrong or inappropriate data it will become an obstacle in the future to the financial reporting process.

Based on data analysis conducted, the application of the Siskeudes application in Tanjungsari Village, Umbulsari District, Jember Regency is well structured. The procedures for using Siskeudes have also been carried out in accordance with applicable regulations. Starting from the planning, budgeting, implementation stage, reporting stage and evaluation stage. Reports on the implementation are made by the staff in charge, namely the Village Treasurer.

The existence of financial applications certainly plays an important role in various things, one of which is in financial management, the existence of financial applications itself has a very 
significant role in managing finances with the aim of producing relevant outputs so as to minimize any problems that may often occur such as reporting delays, even fraud. in financial reports.

The village financial system application (Siskeudes) will find it easy to make analysis related to steps that must be taken in the next period in village development, the village financial system application (Siskeudes) will provide convenience in managing finances not only specifically but thoroughly so that it will make village finances more stable. In addition, the application of the village financial system (Siskeudes) plays a very important role in helping the village head maintain village assets, because all village assets can be recorded in the Siskeudes application, thereby increasing the trust of the village head as the person in charge.

Accountability is the responsibility of the implementation carried out by the village government, if this is related to the role of the financial system application in an effort to increase village financial accountability in the village of Tanjungsari, then the principle of accountability by using the village financial system application (Siskeudes) has been fulfilled, according to the results of research conducted. obtained by researchers, most of the informants said that this village financial application has a role in increasing village financial accountability, with the availability of accountability report information and other outputs that are easily understood by the public and the community can access the results of published village financial reports.

The use of the Siskeudes application in Tanjungsari village has been running well to date, the good category means financial integrity with the use of the village financial system application (Siskeudes) in the category of being able to play a role in improving the quality of village financial accountability, in other words financial integrity by using the village financial system application reflects honesty of presentation. Honesty in presentation means that there must be a relationship or match between accounting numbers and descriptions and their sources, and presenting information openly. However, the application of the village financial system (Siskeudes) is only limited to a system controlled by human resources as managers, meaning that honesty returns to human resources.

The positive impact of the village financial system has made the village government further improve performance so that it can produce effective and efficient financial reports. This shows that the Siskeudes also affects the performance of the village government. This result is in accordance with the purpose of implementing the Siskeudes, namely to help the work of the village government. The readiness of the Tanjungsari village government can also be said to be ready, not free from several obstacles such as what informants from the village government said that there were still errors in the system in the reporting data input process, as well as constraints on human resources. It is better if employees try to coordinate between village governments and village supervisors or assistants to be able to maximize work so that they are able to overcome problems that occur.

The quality of village financial accountability is good if it is transparent. Transparent can be said with the openness of the village government to manage village finances as in line with the vision and mission of the village, in carrying out the transparency of conveying material and relevant financial information regarding government agencies, the village government is obliged to be responsible for everything that happens, especially in terms of transparency of village finances.

The implementation of public services is a state effort to fulfill the basic needs and civil rights of every citizen for goods, services and administrative services provided by public service providers. Public service providers in Indonesia are all state organs such as the Central Government, Local Government, in this case the village government. 


\section{CONCLUSION}

Based on the research conducted by researchers, it can be concluded that the use of the village financial system application (SISKEUDES) in the village of Tanjungsari has been running for one year starting from 2019. Implementation in Tanjungsari village is in accordance with government regulations and all bookkeeping work is carried out properly by financial staff and staff who are of course able to produce village financial reports that are effective and efficient in a time manner and of an accountable quality in general. Although sometimes there are still obstacles in terms of human resources and the application system. The quality of financial accountability in the village of Tanjungsari after the implementation of the village financial system application (Siskeudes) was able to improve the quality of performance and end-of-period reports.

\section{REFERENCE}

Artini, N. M. D., Wahyuni, M. A., \& Herawati, N. T. (2017). Analisis Akuntabilitas Pengelolaan Keuangan Desa Melalui Pengimplementasian Sistem Keuangan Desa (SISKEUDES) dalam konteks disiplin diri pada desa tigawasa. E-Journal S1 Ak Universitas Pendidikan Gane, $8(2), 11$.

BPKP.(2018, 29 Agustus). Petunjuk Pelaksanaan Bimbingan dan Konsultas Pengelolaan Keuangan Desa. Tim penyusun Deputi Bidang Pengawasan Penyelenggaraan Keuangan Daerah. Diperoleh pada 29 Agustus 2018, dari www.desaku-berdaya.com.

Bruno, L. (2019). Proses Penyelesain Percereain Karena Fakror Kekerasan Dalam Rumah Tangga (Studi Kasus Di Pengadilan Agama Surakarta). Journal of Chemical Information and Modeling, 53(9), 1689-1699.

D., Id, M. S., \& Ah, S. (2019). Implementasi permendagri nomor 20 tahun 2018 tentang pengelolaan keuangan desa ditinjau dari.

Faozi, Chusnul. (2014, 5 Maret). Harap-harap Cemas Undang-Undang Desa. Kompasiana. Diperoleh pada 5 Maret 2014, darihttp://kompasiana.com.

Juardi, M. M. (2018). Evaluasi Penggunaan Aplikasi Siskeudes Dalam Upaya Peningkatan Kualitas Akuntabilitas Keuangan Desa. Jurnal Ilmiah Akuntansi Peradaban, IV, 84-107.

Malahika, J. M., Karamoy, H., \& Pusung, R. J. (2018). Penerapan Sistem Keuangan Desa (Siskeudes) Pada Organisasi Pemerintahan Desa (Studi Kasus Di Desa Suwaan Kecamatan Kalawat Kabupaten Minahasa Utara). Going Concern : Jurnal Riset Akuntansi, 14(1), 578583.

Mamesah, D. J. (1995). Sistem Administrasi Keuangan Daerah. Jakarta: PT. Gramedia Pustaka Utama.

Mardiasmo. (2002). Otonomi \& Manajemen Keuangan Daerah. Yogyakarta

Moedarlis, Fajar T. (2016). Sistem Akuntabilitas Keuangan Desa. Hal: 1-17.

Nazir, Mohammad. (1988). Metode Penelitian. Jakarta: Ghalia Indonesia. Hal: 63 Sugiyono. (2017). Metode Penelitian Kuantitatif, Kualitatif, dan R\&D. Bandung: CV.Alfabeta. Hal: 85

Pengelolaan Keuangan Desa Sistem dan Prosedur Pertanggungjawaban Keuangan Desa. Diperoleh pada 15 Januari 2019, darihttps://bppk.kemenkeu.go.id/

Pengelolaan Keuangan Desa Sistem dan Prosedur Pertanggungjawaban Keuangan Desa. Diperoleh pada 15 Januari 2019, dari https://bppk.kemenkeu.go.id/

Peraturan Menteri Dalam Negeri (Permendagri) Nomor 113 Tahun 2014 tentang Pengelolaan Keuangan Desa. Diperoleh pada 15 Agustus 2020, dari http://www.keuangandesa.com/wpcontent/uploads/2015/04/permendagri-No-113-Tahun-2014-Tentang-PengelolaanKeuangan-Desa.pdf

Peraturan Menteri Dalam Negeri (Permendagri) Nomor 20 Tahun 2018 tentang Pengelolaan Keuangan Desa Terbaru. Diperoleh 15 Agustus 2020, dari https://www.kemendagri.go.id

Suharsimi Arikunto \& Cepi Safrudin A.J. (2014). Evaluasi Program Pendidikan. Jakarta: Bumi Aksara. 
Tataan, K. G., \& Ridwan, M. A. (2019). Analisis Peran Aplikasi Sistem Keuangan Desa ( Siskeudes ) Dalam Meningkatkan Kualitas Akuntabilitas Keuangan Desa Di Tinjau Raden Intan Lampung 1440 H / 2019 M Analisis Peran Aplikasi Sistem Keuangan Desa ( Siskeudes ) Dalam Meningkatkan Kualitas 1440 H . 1-140.

Undang-Undang Republik Indonesia Nomor 6 Tahun 2014 tentang Desa. Diperoleh pada 15 Agustus 2020, dari https://www.spi.or.id.

Undang-Undang Republik Indonesia Nomor 6 Tahun 2014 tentang Desa. Diperoleh pada 15 Agustus 2020, dari https://www.spi.or.id.

Welley, M. M., Koleangan, R. A. M., \& Kawung, G. M. V. (2019). Perbandingan Sebelum Dan Sesudah Menggunakan Aplikasi Siskeudes Dalam Pengelolaan Keuangan Desa Dan Dampaknya Terhadap Pembangunan Desa. Jurnal Pembangunan Ekonomi Dan Keuangan Daerah, 19(8), 1-16.

Wirawan. (2011). Evaluasi, Teori, Model, Standar, Aplikasi dan Profesi. Jakarta: Raja Grafindo Persada 